\title{
Money Sense makes a difference
}

\author{
Karen P. Varcoe $\square$ Joan Wright
}

\begin{abstract}
The "Money Sense" program teaches low-income families how to overcome one of their biggest problems, managing finances. As this study shows, the program improves participants' resource management skills and can lead to changes in their quality of life.
\end{abstract}

Financial management is roundly acknowledged as one of the most pervasive problems families face, especially low-income, single-parent families. Individuals and families need guidance to develop the skills that can help them manage their limited resources. Opportunities to learn how to manage these resources, however, are not widely available.

In response to this problem, a team of UC Cooperative Extension home economists and a family economics specialist developed the Money Sense program. With funding from California's Expanded Food and Nutrition Education Program (EFNEP), we began its development at Edwards Air Force Base, a large military reservation in Kern County with a high concentration of low-income enlisted personnel. Money Sense Advisor (MSA) volunteers were trained with the intention that they would then teach what they had learned to clients on a one-to-one or small-group basis.

Money Sense was designed as an educational intervention, not a crisis intervention. Its curriculum deals with the participants' financial problems, helping them clarify their own values and goals, create and follow a budget, keep records, and use good money management skills. Teaching materials included group and individual learning activities, background reading for MSAs, and workbooks and handouts, some of which were translated into Spanish.

After we developed Money Sense at Edwards Air Force Base, it spread to other military installations (Port Hueneme and Point Mugu in Ventura County) and to the Family Violence Center (FVC), a crisis intervention group near Lancaster. Then three rural counties (Humboldt, Mariposa, and Placer) adopted Money Sense with assistance from EFNEP Opportunity funds, as did one urban county (Stanislaus) with an established EFNEP operation.

\section{The study}

We based our assessment on the degree to which clients adopted the family resource management techniques taught in the program. Because MSAs were required to pass a knowledge test before being allowed to teach, we only included the "second generation" learners-the clients-in the study. We focused on what the clients say they do (or at least recognize as appropriate behavior), not what they may know but choose not to practice.

At least 20 clients in each county or major application were interviewed 1 to 3 months after completing the program. Many of the 28 questions consisted of multiple items. Trained interviewers collected data about clients' current behaviors and their comparable behaviors before participation in Money Sense. For example, to assess money management and food shopping skills, we presented a list of skills to the respondents. They were asked which skills they used before Money Sense and which they were using now. Current behaviors were also compared with the prior behaviors and with behaviors reported on enrollment forms.

\section{The sample}

Altogether 190 clients were interviewed, including 21 from Humboldt County, 22 from Placer County, 30 from Stanislaus County, 31 from Port Hueneme, 60 from Edwards Air Force Base, and 26 from the Family Violence Center. Some data were collected from the clients when they enrolled in Money Sense, but those data were anonymous at Edwards Air Force Base, Port Hueneme, and the FVC, so they could not be matched to their follow-up data. Of the 104 persons interviewed in the remaining four counties, 85 could be matched to their enrollment forms.

The 190 clients who participated in the follow-up study ranged in age from 20 to 76 years, with a median age of 30 years. There were 56 males and 129 females in the sample, plus 5 individuals of whose sex we had no record. Thirty-seven were single, 114 married, and 37 separated, divorced, or widowed at the time of interview. Household size ranged from 1 to 7 persons, with an average size of 3 persons. Most respondents (139) were white, 21 were black, 18 Hispanic, 5 Asian, and 2 Native American (no ethnicity data were recorded for the balance of the group).

Among the 183 households about which this information was available, 52 included two wage earners and 106 included only one. Twenty-five households had no wage earner. No employment information was collected from participants at Edwards Air Force Base. Among the remaining respondents, 21 were employed part-time and 46 full-time, 45 were not in the labor force (disabled, retired, full-time students, or homemakers), and 16 were seeking em- ployment. Ninety-five respondents had monthly incomes of less than $\$ 500,55$ had monthly incomes ranging from $\$ 500$ to $\$ 1,000$, and 23 had monthly incomes exceeding $\$ 1,000$. Seventeen respondents supplied no employment data.

\section{Data analysis}

To analyze the data, we used six dependent variables as indicators of program effectiveness: (1) changes in use of food shopping skills, (2) changes in use of money management skills, (3) average weekly food costs per person, (4) food consumption patterns, (5) frequency of money problems, and (6) self-perception of financial status. Using these variables, we ran t-tests to check the significance of differences between the means of "before" and "after" scores on the applicable indicators for all 190 study participants for whom follow-up data were available (table 1). Each measurement of program effectiveness showed a significant change in the intended direction.

A one-way analysis of variance among counties or major applications was conducted for each variable used to measure behavioral changes (table 2). The F-ratio (the variability of measures between locations compared to the variability within locations) is statistically significant for two of the outcome measures, so the extent of change differed significantly among locations only for those two skills: the percentages using new food shopping skills and new money management skills.

Because of differences among the six applications, it was not clear whether our overall data for the total Money Sense population indicated actual changes had occurred within every location. Consequently, we ran separate t-tests to compare before-and-after practices for each location. Placer County participants showed no significant changes in their management skills and Placer and Humboldt county participants showed no changes in weekly perperson food cost. With these exceptions, all differences in means were significant - and all in the intended direction.

\section{Results}

Changes in the reported use of family resource management skills constitute a reasonably direct measure of the extent to which clients learned and were willing to apply new practices. In all reported applications, clients changed their food shopping and money management behaviors in the intended way. The changes were statistically significant in all cases but one-use of money management skills in Placer County. 
As one might expect from the positive changes in food shopping behavior, clients in all applications reported lower food costs (adjusted for family size) after their participation in Money Sense. The change in food costs was not statistically significant in Humboldt and Placer counties. Nevertheless, the difference ranged from $\$ 3.05$ per person per week (est. annual savings per person: $>\$ 150$ ) to $\$ 6.15$ per person per week (est. annual savings per person: $>\$ 300$ ).

Decreased food costs at the expense of good nutrition would be a false economy. Comparisons of the clients' reported food consumption patterns revealed that all Money Sense groups made statistically significant improvements, increasing consumption of fruits, vegetables, and milk products (often underrepresented in Californians' diets), and decreasing consumption of fats, sugars, and high-sodium foods that present potential health risks to the population.

Another hypothesized effect of improvements in family resource management is a decrease in money problems. If clients faced such problems daily or weekly before participating in Money Sense, their new skills should have made those occur-

TABLE 1. Differences in group mean behaviors before and after Money Sense training

\begin{tabular}{|c|c|c|c|c|}
\hline Variable & $\mathbf{N}$ & Mean & t-value & Probability \\
\hline $\begin{array}{l}\text { Percentage of food shopping skills } \\
\text { Used now } \\
\text { Used before Money Sense }\end{array}$ & 175 & $\begin{array}{l}72.50 \\
49.57\end{array}$ & 12.23 & .000 \\
\hline $\begin{array}{l}\text { Percentage of money management skills } \\
\text { Used now } \\
\text { Used before Money Sense }\end{array}$ & 182 & $\begin{array}{l}85.04 \\
60.01\end{array}$ & 13.35 & .000 \\
\hline $\begin{array}{l}\text { Perceived financial status" } \\
\text { Current } \\
\text { Before Money Sense }\end{array}$ & 190 & $\begin{array}{l}2.7158 \\
2.0053\end{array}$ & 12.04 & .000 \\
\hline $\begin{array}{l}\text { Frequency of money problemst } \\
\text { Now } \\
\text { Before Money Sense }\end{array}$ & 190 & $\begin{array}{r}.9211 \\
1.6000\end{array}$ & -6.90 & .000 \\
\hline $\begin{array}{l}\text { Weekly food cost per person } \\
\text { Now } \\
\text { Before Money Sense }\end{array}$ & 167 & $\begin{array}{l}\$ 14.90 \\
\$ 17.16\end{array}$ & -7.11 & .000 \\
\hline $\begin{array}{l}\text { Food Consumption Index } \S \\
\text { Actual score } \\
\text { Score if no change }\end{array}$ & 187 & $\begin{array}{l}2.3251 \\
2.00\end{array}$ & 20.38 & .000 \\
\hline
\end{tabular}

"Possible scores were: 4 (excellent), 3 (good), 2 (fair), 1 (poor).

†Possible scores were: 4 (daily), 3 (weekly), 2 (monthly), 1 (rarely), 0 (none)

§Possible scores were: 3 (desirable change), 2 (no change), 1 (undesirable change).

TABLE 2. Variance in measurable results by site

\begin{tabular}{|c|c|c|c|c|c|c|c|c|}
\hline \multirow{2}{*}{$\begin{array}{l}\text { Change } \\
\text { Measured }\end{array}$} & \multicolumn{6}{|c|}{ Means for each program } & \multirow[b]{2}{*}{ F-ratio } & \multirow[b]{2}{*}{$\begin{array}{l}\text { Signifi- } \\
\text { cance }\end{array}$} \\
\hline & Edwards & Humboldt & Placer & Stanislaus & Ventura & FVC & & \\
\hline \multirow{3}{*}{$\begin{array}{l}\text { Percentage of food } \\
\text { shopping skills } \\
\text { Percentage of money } \\
\text { management skills } \\
\text { Perception of } \\
\text { financial status } \\
\text { Frequency of }\end{array}$} & 0.29 & 0.16 & 0.11 & 0.22 & 0.23 & 0.27 & 2.290 & .048 \\
\hline & 0.27 & 0.23 & 0.03 & 0.25 & 0.30 & 0.39 & 5.559 & .000 \\
\hline & 0.82 & 0.48 & 0.41 & 0.73 & 0.94 & 0.62 & 1.740 & .127 \\
\hline $\begin{array}{l}\text { money problems } \\
\text { Weekly per-person }\end{array}$ & 0.77 & 0.65 & 0.41 & 0.67 & 0.77 & 0.96 & .553 & .736 \\
\hline $\begin{array}{l}\text { food cost } \\
\text { Food Consumption }\end{array}$ & 5.95 & 3.09 & 3.91 & 4.89 & 4.16 & 6.15 & .484 & .788 \\
\hline Index & 2.32 & 2.42 & 2.24 & 2.31 & 2.34 & 2.33 & 1.378 & .234 \\
\hline
\end{tabular}

(accompanied by improved food consumption patterns), less frequent financial problems, and more positive perception of their financial status. The magnitude of these results is greater where Money Sense has been in operation for 2 years or more than where it is in its first year, still getting established. Money Sense is effective for a wide variety of clientele, and its effectiveness is likely to increase with maturity of each local program.

The study also found that clients who started out with fewer resource management skills were likely to make more changes than those with more skills, so intervention did help those who needed it most. Judging from the participants' comments, however, even those who were managing their resources well before Money Sense felt the program had helped them. In the final assessment, those who had the greatest room for improvement may not have ended up with the best skills, but they made the most improvement. For limited-resource clients, these improvements can mean a major change in their quality of life-and this is the program's ultimate goal.

Money Sense is more accurately described as a curriculum than as a programa set of learning modules that can be adapted to particular populations. Although it was designed for delivery through trained volunteers serving as peer advisors, many variations on that strategy proved to be workable and effective. The program may reach its clientele through the GAIN (Greater Avenues for Independence) program, a local housing authority, a WIC (Women, Infants, and Children Program) clinic, an Indian Health Center, or a classroom for pregnant and parenting teens. Appropriate content units can be selected for each setting, and teachers should develop examples and learning activities that are meaningful to their clients.

What is the future of Money Sense? Edwards Air Force Base and Port Hueneme now administer the program at their sites with Cooperative Extension assistance, and other bases have begun programs. Programs also continue in nonmilitary settings, but funding continues to be a problem. Most counties are continuing the program at some level. The program has been initiated at new sites, and we hope it will continue to expand. The program's effectiveness is a strong inducement for Extension advisors to adapt the curriculum to their own situations.

Karen P. Varcoe is Consumer Economics/Management Specialist, Cooperative Extension, University of California, Riverside; and Joan Wright is Education Research Specialist, Department of Applied Behavioral Science, UC Davis. 